\title{
Cadmium determination in urine by atomic absorption spectrometry as a screening test in industrial medicine
}

\author{
G. LEHNERT, G. KLAVIS, K. H. SCHALLER, AND T. HAAS \\ Department of Occupational and Social Medicine of the University of Erlangen-Nürnberg, \\ and the Institute of Occupational Medicine of Niedersachsen, Hannover, Germany
}

\begin{abstract}
Lehnert, G., Klavis, G., Schaller, K. H., and Haas, T. (1969). Brit. J. industr. Med., 26, 156-158. Cadmium determination in urine by atomic absorption spectrometry as a screening test in industrial medicine. Cadmium was determined by atomic absorption spectrometry in the urine and serum of 18 workers exposed to cadmium dust and fume in a zinc smelting plant. In all cases the concentrations of cadmium in the serum were within the normal range, but those in "the urine were elevated. The elevated urine concentrations showed that the exposed group had taken up more cadmium than normal, although they showed no clinical symptoms of cadmium poisoning. Analysis of urine for cadmium is therefore of value in preventive medicine, and should be used for periodic check-ups on those occupationally exposed.
\end{abstract}

Today cadmium is mainly used as a component of low melting alloys, in pigment manufacture, in electroplating, and in the making of cadmium accumulators. The significance of cadmium for industrial medicine lies in the fact that closely above its melting point its vapour pressure is so high that toxic vapour concentrations may result. The risk to health is mainly associated with the production of alloys containing cadmium and cadmium-coated metals, especially with smelting, casting, welding, and cutting.

The signs and clinical characteristics of the toxic effects of cadmium have been reported in several publications and were summarized by Baader (1960), Browning (1961), Hunter (1962), and Koelsch $(1962,1963,1966)$. Whereas the diagnosis of acute intoxication is relatively easy, signs of chronic poisoning could be overlooked. As with other toxic metals (Lehnert, 1968), estimations of cadmium in biological specimens from people occupationally exposed may be used to diagnose incipient poisoning and to monitor the working environment. Atomic absorption spectrometry both simplifies and increases the precision of cadmium estimations (Lehnert,
Schaller, and Haas, 1968). Our first results using this method on urine and serum from exposed workers are reported here.

\section{The exposed group}

The group consisted of 18 workers in a zinc smelting plant. Regular medical examinations since the beginning of 1967 had failed to reveal any clinical symptoms attributable to cadmium. There was, however, undoubtedly exposure to cadmium, as the dusts in the roasting plant contained 0.05 to $3 \%$ cadmium as well as zinc, lead or mercury. Cadmium was present usually as the sulphide, but in the zinc plant the cadmium fumes leaving the distillation furnace were burnt to cadmium oxide.

\section{Materials and methods}

Cadmium determinations in serum and urine were performed as described by Lehnert and his colleagues (1968). The urine specimens were collected in polyethylene bottles, which had previously been rinsed with nitric acid $(1: 3)$. The blood was drawn with plastic syringes and needles which were used only once. All 
glass material was washed with nitric acid and distilled water. Ten millilitres of serum or $50 \mathrm{ml}$. of urine were wet ashed with $10 \mathrm{ml} .65 \% \mathrm{HNO}_{3}, 5 \mathrm{ml} .96 \% \mathrm{H}_{2} \mathrm{SO}_{4}$, and $5 \mathrm{ml} .70 \% \mathrm{HClO}_{4}$. The white residues were dissolved in dilute hydrochloric acid and adjusted to $p \mathrm{H} 2.5$ using a $p \mathrm{H}$ meter. Two millilitres of $5 \%$ aqueous ammoniumpyrrolidine dithiocarbamate solution were added forming a cadmium chelate, which was extracted into $2 \mathrm{ml}$. methyl isobutylketone (MIBK).

For the final measurement in the organic phase a Beckman atomic absorption spectrometer was used in combination with a Beckman spectrophotometer DU (lamp current, $5 \mathrm{~mA}$; turbulent flow burner assembly with three sprayer burners; triple-pass; air pressure, 11 psi; hydrogen pressure, 2 psi; slit, $0.06 \mathrm{~mm}$.; wavelength $2288 \AA$ (228.8 nm.); 10-in. recorder). The instrument was calibrated with standard solutions treated in the same way. With the given instrument settings a detection limit of $0.012 \mu \mathrm{g}$. cadmium/100 ml. urine or $0.06 \mu \mathrm{g}$. cadmium $/ 100 \mathrm{ml}$. serum could be obtained. Sensitivity could be slightly improved by reducing the volume of organic solvent using the improved hollow cathode lamp and by expanding the scale. The precision of the method was $\pm 10 \%$, and mean recoveries were $96 \%$.

Cadmium levels in the urine were corrected to creatinine content and are expressed as $\mu \mathrm{g}$. cadmium/g. creatinine.

\section{Results and discussion}

Lehnert and his colleagues (1968) found that, in specimens taken from adults who had not been exposed to cadmium in the course of their work, the cadmium concentrations were $0.33 \pm 0.24 \mu \mathrm{g} . / 100$ ml. serum (mean \pm S.D.) and in urine $0.63 \pm 0.34$ $\mu \mathrm{g} . / \mathrm{g}$. creatinine (24-hour excretion in urine was $0.98 \pm 0.36 \mu \mathrm{g}$.)

In specimens from exposed workers (Table) all the serum concentrations were within 3 standard deviations of the normal mean and could not, therefore, be regarded as abnormal; but urines from 14 of the 18 persons examined exceeded the normal average urine concentration by more than 3 standard deviations. There was no correlation between the duration of exposure to cadmium and cadmium concentrations in either the serum (correlation coefficient $=-0.124$ ) or the urine (correlation coefficient $=0.060$ ) (see also the Figure). This is in agreement with our experience with other heavy metals (Lehnert, 1968).

The discrepancy between the (normal) serum cadmium concentrations and the (pathological) rates of cadmium elimination is remarkable. There was no correlation between these variables $(r=-0 \cdot 377)$, since theoretically a dynamic steady state should exist between the cadmium-influx, -interflux, and -efflux. The incongruity might be explained if, as Friberg (1952) states, cadmium is mainly bound to the erythrocytes. We will examine this question in further studies to be reported later.

As there were no clinical signs which could be attributed to cadmium the increased urinary cadmium did not indicate cadmium poisoning. The

TABLE

Determination of CD (II) in Serum and Urine of 18 Cadmium-exposed Workers

\begin{tabular}{|c|c|c|c|c|c|}
\hline \multirow[b]{2}{*}{ Name } & \multirow[b]{2}{*}{$\begin{array}{c}\text { Age } \\
\text { (years) }\end{array}$} & \multirow[b]{2}{*}{ Work-place } & \multirow[b]{2}{*}{$\begin{array}{l}\text { Exposure } \\
\text { (years) }\end{array}$} & \multicolumn{2}{|c|}{ Analyses } \\
\hline & & & & $\begin{array}{c}\text { Serum } \\
(\mu g . C d(I I) / 100 ~ m l .)\end{array}$ & $\begin{array}{c}\text { Urine } \\
(\mu g . C d(I I) / g . \text { creat. })\end{array}$ \\
\hline $\begin{array}{l}\text { B.F. } \\
\text { D.W. } \\
\text { D.H. } \\
\text { F.G. } \\
\text { G.A. } \\
\text { H.W. } \\
\text { K.D. } \\
\text { K.A. } \\
\text { M.H. } \\
\text { P.K. } \\
\text { P.J. } \\
\text { P.H. } \\
\text { R.H. } \\
\text { R.H. } \\
\text { S.A. } \\
\text { S.E. } \\
\text { T.G. } \\
\text { T.H. }\end{array}$ & $\begin{array}{l}36 \\
28 \\
35 \\
38 \\
49 \\
38 \\
37 \\
46 \\
31 \\
59 \\
34 \\
41 \\
34 \\
31 \\
56 \\
30 \\
35 \\
51\end{array}$ & $\begin{array}{l}\text { Roasting plant } \\
\text { Roasting plant } \\
\text { Mercury plant } \\
\text { Fine zinc plant } \\
\text { Mercury plant } \\
\text { Mercury plant } \\
\text { Roasting plant } \\
\text { Roasting plant } \\
\text { Fine zinc plant } \\
\text { Fine zinc plant } \\
\text { Mercury plant } \\
\text { Fine zinc plant } \\
\text { Mercury plant } \\
\text { Electroplating process } \\
\text { Roasting plant } \\
\text { Roasting plant } \\
\text { Roasting plant } \\
\text { Roasting plant }\end{array}$ & $\begin{array}{l}2 \\
10 \\
12 \\
2 \cdot 5 \\
4 \\
11 \\
18 \\
4 \\
11 \\
11 \\
0 \cdot 055 \\
10 \cdot 5 \\
9 \\
8 \\
5 \\
1 \\
20 \\
10\end{array}$ & $\begin{array}{l}0 \cdot 08 \\
0 \cdot 04 \\
0 \cdot 23 \\
0 \cdot 90 \\
0 \cdot 17 \\
0 \cdot 25 \\
0 \cdot 36 \\
- \\
0 \cdot 0 \\
0 \cdot 15 \\
0 \cdot 07 \\
0 \cdot 24 \\
0 \cdot 05 \\
0 \cdot 14 \\
0 \cdot 32 \\
0 \cdot 11 \\
0 \cdot 11 \\
0 \cdot 0\end{array}$ & $\begin{array}{l}2 \cdot 55 \\
2 \cdot 05 \\
1.48 \\
0 \cdot 80 \\
3 \cdot 60 \\
1 \cdot 40 \\
3 \cdot 91 \\
5 \cdot 62 \\
2 \cdot 71 \\
5 \cdot 31 \\
5 \cdot 60 \\
3 \cdot 40 \\
2 \cdot 62 \\
2 \cdot 72 \\
2 \cdot 56 \\
1 \cdot 15 \\
3 \cdot 43 \\
6 \cdot 17\end{array}$ \\
\hline & & & & $0.0-0.90$ & $1 \cdot 15-6 \cdot 17^{1}$ \\
\hline
\end{tabular}

${ }^{1}$ Mean differs from mean of normals $(\mathrm{P}<0.001)$ 


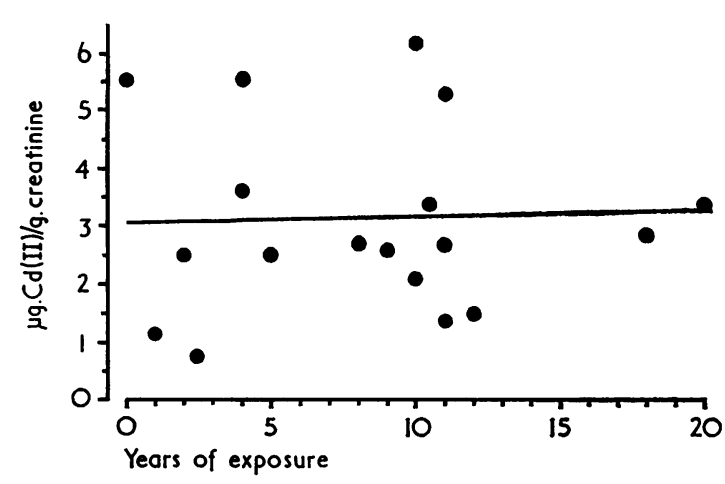

FIGURE Urinary cadmium plotted against years of exposure for the 18 workers from a zinc smelting plant: correlation coefficient $(\mathrm{r})=0.06 ; \mu \mathrm{g} . \mathrm{Cd} / \mathrm{g}$. creatinine $=$ $3.05+0.18 \times$ years.

results, however, indicate an increased uptake of cadmium. The analysis of urine from workers believed to be exposed can be used to monitor the working conditions, and periodical estimations should make it possible to introduce protective measures in time to prevent the development of organic damage.

\section{References}

Baader, E. W. (1960). Klinische Grundlagen der sechsundvierzig meldepflichtigen Berufskrankheiten. Urban and Schwarzenberg, Munich.

Browning, E. (1961). Toxicity of Industrial Metals. Butterworths, London.

Friberg, L. (1952). Further investigations on chronic cadmium poisoning. Arch. ind. Hyg. occup. Med., 5, 30-36.

Hunter, D. (1962). The Diseases of Occupations, 3rd ed. Little, Brown, Boston.

Koelsch, F. (1962). Handbuch der Berufskrankheiten. Fischer, Jena. (1963). Lehrbuch der Arbeitsmedizin, 4th ed., vol. 1. Enke, Stuttgart.

(1966). Lehrbuch der Arbeitsmedizin, 4th ed., vol. 2. Enke, Stuttgart.

Lehnert, G. (1968). Der Blutbleispiegel und seine Bedeutung für die Pathogenese und Prävention der beruflich bedingten Bleivergiftung. Gentner, Stuttgart.

- Schaller, K. H., and Haas, T. (1968). Atomabsorptionsspektrometrische Cadmiumbestimmung in Serum und Harn. Z. klin. Chem., 6, 174-176.

Received for publication July 15, 1968. 